\title{
Resistensi Perempuan Multikultural dalam Karya Sastra Indonesia (Kajian Berperspektif Feminis)
}

\author{
Syukrina Rahmawati*)
}

\section{Pengantar}

Perempuan di Indonesia memiliki kewenangan tersendiri dalam menunjukkan eksistensi sosial di tengah-tengah konstruksi masyarakat yang multikultural. Hal ini ditunjukkan atas dasar perempuan di Indonesia sebagai bagian dari terbentuknya kebudayaan yang beraneka ragam di tengah-tengah kehidupan sosial masyarakat. Dalam interrelasi perempuan dan budaya, sumber konflik masyarakat secara umum tidak jauh dari pandangan bahwa terdapat kebimbangan-kebimbangan tekstual yang mengacu pada realitas. Berdasarkan pendapat dari kaum feminis, perempuan merupakan suatu kelas dalam masyarakat yang ditindas oleh kelas lai, yaitu laki-laki. Sesuai dengan tulisan Engels dalam Origin of the Family, Private Property and the State yang mengatakan bahwa: "dalam keluarga, dia (suami) adalah borjuis dan istri mewakili kaum proletar."

Karya sastra merupakan salah satu atribut massa yang menyuarakan hak-hak perempuan. Kehadirannya menjadi informasi bagi para pembaca tentang pergulatan bentuk-bentuk resistensi perempuan terhadap budaya yang mengikat. Keberadaan perempuan dalam karya sastra juga sebagai suatu perwujudan adanya semboyan "tersembunyi" pada diri seorang perempuan mengenai keadaan yang sesungguhnya dari keterlibatannya dalam konstruksi suatu masyarakat. Seperti yang dikemukakan oleh Damono dalam artikel "Perempuan Ilalang:

\footnotetext{
*) Sarjana Pendidikan Universitas Mataram
} 
Perempuan dalam Sastra" (2007) bahwa peristiwa-peristiwa yang terjadi dalam batin seseorang, yang sering menjadi bahan sastra, adalah pantulan hubungan seseorang dengan orang lain atau dengan masyarakat. Tak terkecuali hubungan gender antara perempuan dengan laki-laki, perempuan dengan perempuan, atau perempuan dengan lingkungannya.

Puncak dari semua permasalahan yang terjadi pada kehidupan seorang perempuan telah menjadi sumber inspiratif bagi para pengarang perempuan bahkan laki-laki untuk menciptakan suatu karya yang mewakili kenyataan akan hidup keseharian dari seorang perempuan. Posisi perempuan yang dianggap sebagai warga kelas dua/the Other/Liyan merupakan bukti nyata semenjak dahulu perempuan diistilahkan sebagai warga setelah laki-laki, tidak ada perlakuan istimewa yang dapat mengangkat perempuan menjadi setara dengan laki-laki atau bahkan berada di atas laki-laki, tentunya itu suatu hal yang sepertinya mustahil terjadi. Seperti yang dikemukakan oleh Michelle Rosaldo ${ }^{1}$ dalam Arnold (1989:95) bahwa:

"The very symbolic and social conceptions that appear to set women apart and to circumscribe their activities may be used by the women as a basis for female solidarity and worth. When men live apart from women, they in fact cannot control them, and unwittingly they may provide them with the symbols and social resources on which to build a society of their own."

Pernyataan Rosaldo di atas, memberikan pengetahuan sesungguhnya mengenai kedudukan perempuan di mata laki-laki. Begitu pula dengan perempuan yang menganggap dirinya/kelompoknya merupakan satu kesatuan yang tak dapat dipisahkan karena telah terkonstruksi sedemikian rupa. Laki-laki pada kenyataannya tidak ingin

\footnotetext{
${ }^{1}$ Elizabeth Hardwick, Seduction and Betrayal (New York, 1974)
} 
dikontrol oleh perempuan dan tanpa disadari mereka telah membuat simbol-simbol sendiri yang hanya dikenal pada komunitas mereka tanpa campur tangan perempuan. Dengan demikian, terdapat suatu perbedaan yang mendasar antara penulis perempuan dan penulis laki-laki.

Sebagian besar perempuan dalam karya sastra dikisahkan sebagai tokoh yang inferior. Stereotip yang disimbolisasikan pada perempuan mengukuhkan posisi perempuan yang tak akan pernah bisa sama dengan laki-laki karena diyakinkan bahwa marjinalisasi pada perempuan adalah cara melihat atau cara pandang masyarakat umum menilai kedudukan laki-laki dan perempuan. Hal tersebut (perempuan dalam karya sastra) menjadi representasi dari kehidupan sehari-hari pada perempuan di Indonesia yang masih terikat akan budaya patriarki. Patriarki didasarkan pada pandangan bahwa perempuan hanya menjadi pelengkap dan di kontrol oleh laki-laki. Menurut Mohanty melalui Hayat \& Surur (2005:50) mengungkapkan juga karena perempuan kemudian dibentuk sebagai kelompok yang koheren, maka perbedaan jenis kelamin memiliki batas yang sama dengan subordinasi perempuan, dan kekuasaan secara otomatis didefinisikan dalam arti biner: orang yang memilikinya (baca: laki-laki) dan orang yang tidak memilikinya (baca: perempuan).

Makalah ini mencoba membongkar status dan pandangan secara umum suatu kelompok masyarakat terhadap kedudukan perempuan terutama perempuan-perempuan multikultural yang direpresentasikan dalam karya sastra. Perwujudan perempuan multikultural dalam karya sastra adalah realitas yang semu karena resistensi mereka selalu dipertanyakan. Tarian Bumi karya Oka Rusmini dan Ronggeng Dukuh Paruk karya Ahmad Tohari merupakan salah satu contoh karya sastra dari sekian banyak karya sastra yang menguak perempuan dibalik belenggu budaya dan tradisi yang memenjarakan hak dan keinginan 
untuk membuat suatu keputusan. Pertanyaannya adalah bagaimana bentuk resistensi perempuan sebagai warga "kelas dua" atau the Liyan dan kaum yang subaltern dalam memperlihatkan eksistensi dirinya di tengah-tengah pergolakan adat dan tradisi Nusantara yang begitu mengekang? Bagaimana sudut pandang feminis dalam mengkaji perempuan multikultural dalam karya sastra Indonesia, dalam hal ini novel Tarian Bumi karya Oka Rusmini dan Ronggeng Dukuh Paruk karya Ahmad Tohari?

\section{Pembahasan}

\subsection{The Liyan dan Kaum Subaltern: Sebuah Resistensi}

Peranan dan posisi perempuan dalam masyarakat dimaknai oleh bentuk nilai dan norma yang secara langsung diciptakan oleh budaya patriarki. Budaya patriarki, budaya yang menomorsatukan laki-laki yang masih kuat dipegang oleh masyarakat kita yang menempatkan penderitaan perempuan bersifat lintas agama, kesukuan maupun atributatribut lainnya (Baso dalam Hayat \& Surur, 2005:5). Penerimaan perempuan sebagai warga "kelas dua" atau the Other (yang lain) menimbulkan ambivalensi antara berada pada posisi yang diatur dan dikontrol dengan penolakan dan pemberontakan diri terhadap ornamen budaya yang telah mengekang hak-hak mereka sebagai manusia seutuhnya.

Adanya perempuan sebagai the other ini menimbulkan alienasi terhadap dirinya. Perempuan dibatasi hanya sebagai pemilik rahim "Tota mulier in utero" atau "woman is womb". Padahal manusia menurut eksistensialisme manusia dikutuk bebas (Man is condemned to be free) termasuk manusia perempuan. Hanya saja pada perempuan, dalam relasi sosial, laki-laki melihatnya sebagai objek dan eksistensinya selalu 
dibayangi oleh eksistensi orang lain (Arivia dalam Pelatihan Kritik Sastra Kajian Feminis, 2005:14). Eksistensi seorang perempuan tidak pernah dilihat sebagai satu kesatuan dari bagian kehidupan sosial masyarakat, tetapi memperlihatkan hegemoni individual terhadap kekuasaan yang mendoktrinisasikan perbedaan laki-laki dan perempuan. Perempuan hanya dianggap sebagai objek pendukung.

Sang Liyan (the other) terbentuk dan koheren dalam suatu konstruksi sosial. Penamaan oleh "kaum yang terpinggirkan" merupakan bentuk kekuasaan yang dipraktikkan dalam diskursus. Perempuan dijadikan sebagai salah satu kategori, membangun isu yang berkembang bahwa perempuan dianggap sebagai subjek politik seksual sebelum masuk ke dalam struktur kekerabatan. Wacana seks menjadi pokok utama perempuan melakukan sebuah resistensi karena perempuan lebih dikenal sebagai "produk" menghasilkan manusia-manusia baru yang dipertanggungjawabkan agar memperoleh kedudukan sebaik-baiknya di tengah pergolakan politik masyarakat.

Korelasi antara the Liyan dan kaum subaltern menjadi rangkaian stereotip perempuan akan kedudukan dan peranannya dalam kaitannya dengan tradisi. Menurut Gramsci, kelas-kelas subaltern adalah mereka yang disubordinasikan oleh struktur kekuasaan yang dominan, dipinggirkan dari representasi politik. Apabila dalam konsep hegemoni Gramsci kaum intelektual memiliki peran untuk menegosiasikan perubahan dalam struktur kekuasaan, kaum subaltern, yang dimarginalisasi di luar sistem dibuat tidak memiliki posisi yang seperti itu (Budianta dalam Hayat \& Surur, 2005:91). Pembentukan istilah kaum Subaltern juga merupakan bagian dari peradaban postkolonial mengenai perempuan yang identik sebagai makhluk "yang terjajah". 
Kaum subaltern (perempuan) dikondisikan sebagai objek yang dijerat akan nilai-nilai dan norma-norma tradisi masyarakat. Keadaan demikian menjadi suatu bagian dalam sosial-budaya. Pelaksanaan kegiatan tradisi masyarakat bertendensi akibat budaya patriarki, dengan kata lain hal tersebut adalah upaya konstruksi sosial yang membuktikan adanya kaum subaltern memarjinalisasi perempuan lain. Kenyataannya menjadi demikian disebabkan di antara para perempuan terdapat kompetisi-kompetisi dalam rangka mempertahankan hidup. Akibatnya, perempuan yang juga subaltern dapat memihak dan membela adanya patriarki.

Posisi perempuan yang ambivalen di wilayah abu-abu ini, seperti dalam poligami, pornografi, memunculkan masalah bagi gerakan perempuan dan feminisme pada umumnya. Karena melibatkan perempuan dalam masyarakat tradisional dan adat, feminis humanis dan Barat masih belum dapat menentukan sikap apa yang dibenarkan "secara politik" yang harus mereka ambil terhadap klitodermi, dan praktikpraktik tradisional lainnya, yang dari standar tertentu bisa dilihat sebagai pelanggaran hak asasi manusia. (Budianta dalam Hayat \& Surur, 2005:91).

Dengan demikian, realisasi penamaan terhadap perempuan didasarkan pada status sosial masyarakat di bawah kekuasaan yang didominasi oleh budaya setempat (patriarki). Perempuan (Indonesia) sebagai liyan menjadi perwujudan bentuk perempuan dunia ketiga dalam hal identitas dan relasi kuasa yang sangat kompleks. Oposisi biner memperjelas kedudukan perempuan multikultural yang ada di Indonesia maupun perempuan di belahan dunia lain akan julukan laki/perempuan, aktif/pasif, kuat/lemah, superior/inferior, penjajah/terjajah, dan sebagainya. Namun, perempuan dapat mempertahankan jati dirinya 
sebagai makhluk sosial dengan nilai dan norma masyarakat yang sudah terlanjur oleh dominasi kekuasaan dari laki-laki

\subsection{Perempuan Multikultural dan Feminisme dalam Sastra Indonesia}

Perempuan dalam teks sastra tidak jauh berbeda dengan realitas karena cerita dalam teks sastra merupakan perwujudan representasi dari kenyataan. Penggambaran yang diangkat tentang perempuan sekaligus bentuk pernyataan dan resistensi bahwa keberadaan mereka tidak dapat dipungkiri. Problematika yang terus terjadi pada perempuan khususnya di Indonesia menjadi cerita yang tidak ada akhirnya di dunia kesusastraan Indonesia karena penindasan terhadap perempuan ters-menerus terjadi baik oleh laki-laki maupun oleh perempuan sendiri.

Permasalahan-permasalahan perempuan yang timbul di setiap penjuru Indonesia didorong oleh faktor konflik pribadi dengan lingkungan bahkan dengan keluarga terutama terhadap suami (laki-laki), yang dikenal oleh perempuan sebagai pelindung dan pengayom bagi diri mereka sendiri. Sebagaimana perempuan diproyeksikan sebagai warga kelas dua dalam lapisan masyarakat, kemungkinan-kemungkinan buruk bisa saja terjadi antara perempuan tersebut. Semua itu diakibatkan adanya perbedaan sendiri dalam komunitas perempuan. Kemudian teori yang menyangkut perbedaan hingga menimbulkan konflik di antara perempuan sendiri adalah teori feminisme multikultural dan global.

\section{Menurut Arivia:}

Teori ini mempermasalahkan ide bahwa ketertindasan perempuan itu "satu definisi", artinya hanya dilihat bahwa ketertindasan terhadap perempuan terjadi dalam masyarakat patriarkhal. Padahal menurut feminisme multikultural ketertindasan perempuan berkaitan dengan ras, kelas, preferensi seksual, umur, agama, pendidikan, kesempatan kerja 
dsb. Feminis multikultural gelisah melihat teori feminisme yang gagal membedakan perempuan kulit putih dan dari negara maju serta perempuan kulit berwarna dari negara berkembang.

Ungkapan Arivia membuktikan bahwa perempuan yang berada di dunia ketiga telah mengalami sejuta persoalan yang disebabkan dari budaya patriarki, tetapi hal itu tidak cukup sampai di sana karena adanya permasalahan yang lebih kompleks. Perbedaan ras, kelas, umur, agama, pendidikan, dan kesempatan kerja di antara perempuan dapat menjadi pemicu utama timbulnya suatu konflik yang berkepanjangan. Perkembangan gejala secara ideologis, multikulturalisme sangat mengagungkan adanya perbedaan budaya yang mengakui dan mendorong terwujudnya pluralisme budaya sebagai corak kehidupan kemasyarakatan. Multikulturalisme didasarkan pada keyakinan bahwa semua kelompok budaya secara sosial dapat diwujudkan, direpresentasikan, dan dapat hidup berdampingan. Selain itu, diyakini pula bahwa rasisme dapat direduksi oleh penetapan citra positif keanekaragaman etnik dan melalui pengetahuan kebudayaan-kebudayaan lain (Mahayana, 2005:297)

Tarian Bumi (TB) karya Oka Rusmini dan Ronggeng Dukuh Paruk (RDP) karya Ahmad Tohari adalah dua contoh novel yang berlatar belakang kisah para perempuan multikultural yang ada di Indonesia. Pada dasarnya, masih banyak karya-karya sastra lain yang menunjukkan tokoh utama perempuan multikultural di Indonesia seperti Siti Nurbaya karya Marah Rusli, Salah Asuhan karya Abdul Muis, Sukreni Gadis Bali karya A.A. Panji Tisna, Pada Sebuah Kapal karya NH. Dini, dan sebagainya. TB dan RDP menyiratkan problematika perempuan yang sering dihadapi di tengah-tengah pengagungan dewa-dewa atau roh nenek moyang. Problematika tersebut menjadi kajian utama para feminis 
116 Mabasan - Vol. 3 No. 2 Juli-Desember 2009: 108--122

multikultural dikarenakan stereotipe perempuan benar-benar telah tampak dan membudaya dalam masyarakat Indonesia. Wacana yang timbul pada kedua novel itu mengacu pada operasi dominasi laki-laki dan penindasan perempuan yang bersifat lintas budaya dan universal.

\subsubsection{Tarian Bumi (TB) karya Oka Rusmini}

Novel Oka Rusmini yang fenomenal mendapat apresiasi yang antusias dari kaum feminis karena berisi tentang sebuah gugatan perempuan Bali yang dikekang oleh tradisi budaya patriarki. Peranan maskulin sangat kental mendominasi feminin. Dengan kata lain, novel ini menjadi salah satu bentuk pemberontakan perempuan terhadap realitas sosial. Tata sosial yang hierarkis lewat pembagian kasta, patriarkal di mana kaum laki-laki lebih banyak mendapatkan previlese social, merupakan masalah-masalah fundamental yang dihadapi kaum perempuan di Bali, jika ingin menemukan hubungan yang relatif lebih equal dan lebih emansipatoris

Tokoh-tokoh perempuan Bali yang menjadi sorotan diantaranya: Luh Sekar dan Ida Ayu Telaga Pidada (ibu dan anak), dan Luh Kenten (sahabat Luh Sekar). Ketiga tokoh perempuan ini memberikan gambaran kepada pembaca terhadap bentuk-bentuk resistensi seorang perempuan dalam menghadapi konflik sosial-budaya Bali terutama yang memosisikan perempuan sebagai objek pendukung sebuah tradisi. Seperti pada Luh Sekar yang berkasta sudra (kasta rendah) yang bersikeras ingin menikah dengan laki-laki berkasta tinggi (bangsawan).

Aku capek miskin, Kenten. Kau harus tahu itu. tolonglah, carikan aku seorang Ida Bagus. Apa pun syarat yang harus kubayar, aku siap! (TB: 17) 
Luh Sekar (menjunjung tinggi nilai kebangswanan) sebagai perempuan yang menjadi bagian konstruksi sosial melakukan suatu perilaku yang menurutnya pantas dilakukan agar kedudukannya lebih terhormat. Dengan cara apa pun harus dilakukan seorang perempuan Bali untuk memperoleh laki-laki bangsawan yang diinginkan termasuk "membayar mahal" status kebangsawanan laki-laki. Bagi perempuan Bali, tradisi di atas segala-galanya sehingga mereka tidak boleh mempertanyakan, menggugat apalagi mendobrak. Lelaki menjadi puncak kekuasaan. Peran laki-laki Bali sangat dominan dalam kehidupan masyarakat.

Berbeda dengan tokoh Telaga anaknya, yang beranggapan bahwa kasta brahmana (bangsawan) penuh dengan kebohongan dan kemunafikan. Dia mencintai seorang laki-laki sederhana berkasta sudra (Wayan Sasmitha), seorang pelukis. Kehidupan Telaga lebih sejahtera (meskipun sederhana) daripada Luh Sekar yang menikah dengan seorang bangsawan, tetapi tidak bahagia karena suaminya pemabuk dan bercinta dengan sembarang perempuan.

Selanjutnya, tokoh Luh Kenten (sahabat Luh Sekar) memiliki karakter yang berbeda dari perempuan-perempuan lainnya. Diam-diam, ia mencintai Luh Sekar sebagai seorang kekasih. Ia selalu berupaya keras melawan perasaannya sendiri, bahkan ketika sahabatnya bertelanjang bulat di hadapannya. Budaya patriarki yang mengekang telah memengaruhi cara berpikir dan pergulatan batin Luh Kenten yang merasa dirinya tidak pernah tertarik dengan satu lelaki pun. Ia termasuk perempuan yang tidak dianugerahi pembuktian diri sebagai makhluk Hawa sesungguhnya. Ia tidak nyaman dengan ciri khas keperempuanan yang melekat pada dirinya. Ia berkata kepada ibunya dengan lantang bahwa ia tidak akan mencintai laki-laki. 
"Kata-katamu seperti perjanjian pada hidup."

"Ya, Meme. Ini aku ucapkan dengan kesungguhan. Aku akan buktikan, kita bisa hidup tanpa laki-laki. Aku akan buktikan ucapan ini."

"Luh!"

"Meme jangan takut. Aku tahu akibat dari pilihan ini."

"Meme ingin cucu darimu."

"Meme jangan mimpi. Kita sudah terlalu kenyang menderita. Jangan membuat hidup ini jadi tambah rumit." (hal 25)

Jadi, tokoh-tokoh perempuan dalam novel TB merupakan representasi sekaligus suara-suara resistensi perempuan Bali dalam mempertanggungjawabkan keeksistensiannya sebagai manusia yang memiliki harkat dan martabat. Terlepas dari pengakuan mereka akan dominasi budaya dan tradisi yang dibuat oleh laki-laki. Pemberontakan yang dilakukan Telaga dan Luh Kenten merupakan suara hati seorang perempuan Bali yang jenuh dan mencoba memberontak budaya (patriarki) tradisi yang mengikat kebebasan mereka untuk memilih dan berpendapat sedangkan Luh Sekar sebagai simbol perempuan yang sangat mengagungkan tradisi sehingga selalu mencoba mempertahankan tradisi kebangsawanan yang melekat dengan mendidik anaknya (Telaga) untuk tetap pada jalur ketaatan terhadap norma-norma tradisi Bali.

\subsubsection{Ronggeng Dukuh Paruk (RDP) karya Ahmad Tohari}

Berikutnya dalam novel RDP dapat dilihat posisi atau kedudukan perempuan di Dukuh Paruk, sebuah daerah perkampungan di tanah Banyumasan, Jawa Tengah. Kedudukan perempuan dalam novel tersebut sangat direndahkan dipandang dari ranah peranan domestik dan reproduktif. Dalam sistem kekeluargaan perempuan hanya dikenal sebagai pelayan suami, sedangkan dalam masyarakat perempuan sebagai objek pemuas seksual laki-laki seperti barang diperdagangkan. 
Tokoh utama perempuan dalam novel ini adalah Srintil. Srintil dipercaya oleh masyarakat Dukuh Paruk sebagai utusan ronggeng dari moyang Ki Secamenggala sehingga ketika mulai menari Srintil dikatakan kemasukan indang ronggeng. Masyarakat sekitarnya telah mempercayai secara turun-temurun bahwa ronggeng dapat menyelamatkan dan membawa ketentraman anggota masyarakat di Dukuh Paruk. Tahap demi tahap dilalui Srintil sebagai bentuk proses pendewasaannya menjadi seorang ronggeng mulai dari upacara pemandian di depan makam Ki Secamenggala hingga pada waktunya ia mengalami ritual puncaknya yakni melalui prosesi yang disebut dengan bukak-klambu.

\begin{abstract}
"Srintil sesudah berusia delapan belas adalah Srintil yang telah mengalami perihnya upacara bukak-klambu. Juga sudah merasakan getirnya ditampik laki-laki idaman. Pada usia semuda itu Srintil juga sudah menjelajahi dunia perhubungan dengan sekian puluh lelaki. Dan jauh sebelum itu tanah airnya, Dukuh Paruk, telah menempanya dalam kemiskinan yang mengakar.” (RDP: 185)
\end{abstract}

Sejak kanak-kanak, Srintil dilatih untuk menjadi ronggeng Dukuh Paruk. Seorang ronggeng dipercaya sebagai bentuk jati diri Dukuh Paruk, di sinilah tampak bahwa perempuan adalah Dewi Tradisi di masyarakatnya. Balutan inferioritas perempuan dalam pandangan superoritas laki-laki yang membuat aturan-aturan tradisi telah mengukung peradaban perempuan sebagai makhluk sosial. Srintil diagung-agungkan, dibatasi pergaulannya, dan diseleksi laki-laki yang akan "memakainya". Seolah-olah perempuan (Srintil) dalam RDP mengalami dua hal yang kontras, tetapi dijunjung tinggi nilai ritualnya, yaitu pengagungan terhadap kepercayaan bahwa Srintil adalah perempuan jelmaan ronggeng-ronggeng sebelumnya sehingga kehadirannya dalam dunia pementasan ronggeng selalu dinanti-nantikan penduduk sekitar. Di sisi lain, secara halus perempuan (Srintil) dijadikan 
120 Mabasan - Vol. 3 No. 2 Juli-Desember 2009: 108--122

sebagai pemuas birahi laki-laki. Pada mulanya Srintil menerima kepercayaan tersebut sebagai warisan leluhur yang harus dijalani akan tetapi peristiwa bukak-klambu menyadarkan dirinya bahwa jati dirinya sebagai perempuan telah dikoyak dan "ditelanjangi" tanpa ada hak memilih.

"Bukak-klambu adalah semacam sayembara, terbuka bagi laki-laki mana pun. Yang disayembarakan adalah keperawanan calon ronggeng. Laki-laki yang dapat menyerahkan sejumlah uang yang ditentukan oeh dukun ronggeng, berhak menikmati virginitas itu" (RDP: 51)

Hal semacam itulah yang dimaksud dengan relasi kuasa antara perempuan yang berada dalam posisi subaltern dan masyarakat/budaya/tradisi yang telah direpresentasikan sendiri. Perempuan tradisi menobatkan perempuan tradisi lain sebagai objek pelaku dari tumbal kegiatan nenek moyang yang telah dipercaya turuntemurun.

Resistensi Srintil sangat tampak pada saat setelah peristiwa pergolakan politik 1965. Ia ingin membuktikan eksistensinya dengan mengubah citra perempuan dalam dirinya dengan cara yang selayaknya. Ia tidak ingin dikenal sebagai ronggeng lagi, tetapi sebagai perempuan seutuhnya yang memiliki harkat dan martabat di tengah-tengah masyarakat Dukuh Paruk. 


\section{Penutup}

Berdasarkan beberapa penjelasan sebelumnya, dapat disimpulkan bahwa bentuk-bentuk resistensi perempuan multikultural di Indonesia mengarah kepada bentuk eksistensi perempuan tersebut dalam mempertahankan jati diri yang dimiliki meskipun terkekang oleh budaya dan tradisi. Berbagai macam cara dilakukan oleh mereka bertujuan hanya ingin mencapai titik kesempurnaan sebagai seorang perempuan yang dihargai kedudukan dan peranannya.

Realisasi dalam sastra Indonesia mengungkapkan bahwa dalam novel Tarian Bumi karya Oka Rusmini dan Ronggeng Dukuh Paruk karya Ahmad Tohari adalah salah satu dari sekian banyak contoh perempuan multikultural yang terikat oleh budaya dan tradisi akibat kepercayaan yang mendalam terhadap sisa-sisa peradaban leluhur nenek moyang. Dengan demikian, memperlihatkan secara jelas bahwa perempuan tetap menjadi makhluk yang diatur, warga kelas dua/the other (terpinggirkan), objek pemuas seksual laki-laki, dan korban tradisi. 


\section{DAFTAR PUSTAKA}

Arnold, Edward. (1989). Modern Literary Theory. New York: Chapman \& Hall.

Bandel, Katrin. (2006). Sastra, Perempuan, Seks. Yogyakarta: Jalasutra.

Bressler, Charles A. (1994). Literary Ciriticsm (An Introduction to Theory and Practice). New Jersey: Upper Saddle River.

Brooks, Ann. (1997). Posfeminisme \& Cultural Studies (Sebuah Pengantar Paling Komprehensif). diterjemahkan oleh S. Kunto Adi Wibowo. Yogyakarta: Jalasutra.

Budianta, Melanie dkk. (2005). "Pelatihan Kritik Sastra" Kajian Feminis. (tidak diterbitkan). Jakarta: FIB UI.

Foucault, Michel. (1976). Ingin Tahu Sejarah Seksualitas. diterjemahkan oleh Rahayu S. Hidayat. Jakarta: Yayasan Obor Indonesia.

Mahayana, Maman S. (2005). Jawaban Sastra Indonesia Sebuah Orientasi Kritik. Jakarta: Bening Publishing.

Rusmini, Oka. (2007). Tarian Bumi. Jakarta: Gramedia.

Sayyid. (2008). Perempuan Ilalang; Perempuan dalam Sastra. 21 April 2008. www.lenterasusastra.com. diakses tanggal 30 Maret 2009. . (2005). Perempuan Multikultural: Negoisasi dan Representasi. Edi Hayat \& Miftahus Surur (Ed.). Jakarta: Desantara.

Sugihastuti \& Suharto. (2005). Kritik Sastra Feminis (Teori dan Aplikasinya). : Yogyakarta: Pustaka Pelajar.

Tohari, Ahmad. (2007). Ronggeng Dukuh Paruk. : Jakarta: Gramedia. 